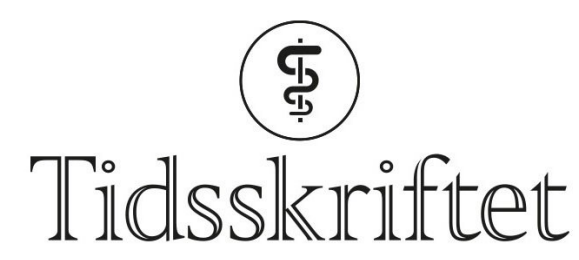

DEN NORSKE LEGEFORENING

\title{
Karl Wilhelm Wefring
}

MINNEORD

HARALD BROCH

MORTEN FALKE

INGER JOHANNE FUGLEVIK

BJØRN HALVORSEN

IVAR HAAGAAS

JOSEF KLEVEN

ALF MEBERG

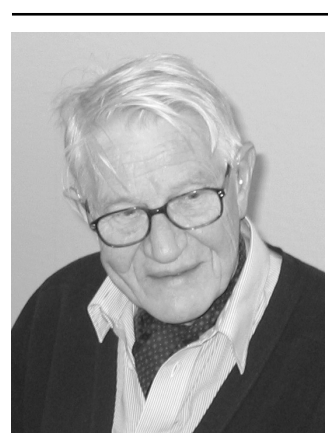

Karl Wilhelm Wefring gikk bort 23. mai 2018, 92 år gammel. Med ham har norsk barnemedisin mistet en av sine store profiler, og vi som i en årrekke hadde gleden av å arbeide sammen med ham har mistet en læremester og venn.

Karl Wilhelm ble godkjent spesialist i barnesykdommer i 1962 og fast ansatt ved barneavdelingen i Tønsberg i 1967. Han ledet avdelingen i årene 1979-1991, deretter avdelingens polikliniske seksjon frem til pensjonsalder. Han var dessuten primus motor for sykehusets historielag. Han ledet Norsk barnelegeforening i 1988-89, og ble senere utnevnt som æresmedlem for sitt arbeid for norsk pediatri. Han er også tildelt Kongens fortjenestemedalje.

Som barnelege var han først og fremst helhetstenkende. Han så barnet i konteksten av familie, nærmiljø og samfunn. Han var en kliniker av «den gamle skolen», der grunnlaget for å stille riktig diagnose var det man så med øynene, hørte med stetoskopet og følte med hendene under undersøkelsen. Og ikke minst var det viktig å lytte til foreldrene. 
Han var også en pioner på andre felter: sammen med overlege Harald Hansen utviklet han et viktig prinsipp (infusjon med kryopresipitat) for å behandle blødersykdom. Han var tidlig ute med blodutskiftning hos nyfødte med alvorlig hyperbilirubinemi, og publiserte viktige forskningsarbeider om K-vitaminbehandling av nyfødte mot alvorlige blødninger.

Som leder av barneavdelingen utviklet Karl Wilhelm, i samarbeid med Fylkeslegen, områdepediatrien i Vestfold. Han var sentral i etablering av habiliteringstjenesten for barn, og sosialpediatri ble et viktig satsingsområde. Allerede i 1972 fikk han opprettet en egen nyfødtmedisinsk enhet lokalisert i sykehuset barselavdeling. På mange måter var dette en forløper for dagens familieorienterte nyfødtmedisin.

Pediatrien er en livsstil, sa han. Denne tilnærmingen bruker vi til å videreutvikle faget og yrkeslivene våre. Vi er stolte over å ha fått føre hans arbeid ved barnesenteret i Tønsberg videre - men det har vært store sko å fylle!

Publisert: 21. august 2018. Tidsskr Nor Legeforen. DOI: 10.4045/tidsskr.18.0465

(C) Tidsskrift for Den norske legeforening 2020. Lastet ned fra tidsskriftet.no 